Journal of the Statistical and Social Inquiry Society of Ireland

Vol. XXXIV

\title{
IMMIGRATION POLICY AND THE SKILLS OF IRISH IMMIGRANTS: EVIDENCE AND THE IMPLICATIONS
}

\author{
Chris Minns \\ Trinity College, Dublin
}

(read before the Society, 24 February 2005)

\begin{abstract}
The rise of immigration into Ireland has been accompanied by a debate on the potential objectives of immigration policy. This paper begins with a survey of international and historical evidence on the economics of immigration policy. To place Irish immigration in the international context, a recent OECD data set is used to compare the education of Irish immigrants to their counterparts in other European economies. The data suggest that Ireland's immigrant population is remarkably skilled. Immigrants of EU origin are positively self-selected. From outside the EU, some countries supply mainly skilled immigrants, while others are sources of less-skilled workers. These findings are used as a backdrop to explore three major issues in Irish immigration: the likely impact of EU accession of new member states, the appropriateness of current immigration policy, and the relationship between current immigration and future population flows.
\end{abstract}

Keywords: Ireland; immigration; immigrant skill; immigration policy

JEL Classifications: J18, J61

\section{INTRODUCTION}

Migration is one of the dominant themes in Irish economic history. Over the last 200 years, it has been primarily a story of emigration. The causes and consequences of large-scale emigration out of Ireland have interested $19^{\text {th }}$ century pamphleteers and political economists (Cairnes, 1873), contemporary economic historians (Hatton and Williamson, 1993, 1998; Ó Gráda and O'Rourke, 1997), and economists interested in post-war Ireland (Walsh, 1974; Barrett, 1999). The last 15 years have seen a marked change in the pattern of Irish migration. Ireland has experience positive net immigration since 1991. This was initially due to large flows of returning Irish emigrants, attracted by improved conditions in the Irish labour market. ${ }^{1}$ Since the late 1990 s, immigrant inflows have seen declining numbers of return migrants, and increasing numbers of foreign-born migrants. A considerable proportion of foreign-born arrivals now consist of immigrants who have no prior ties to Ireland, and flows are increasingly made up of immigrants from non-anglophone countries.

The transformation of Irish migration has lead to a growing debate regarding immigration policy. This has been a major policy issue in North America since the mid- $19^{\text {th }}$ century, and within Europe since (at least) the end of the Second World War. Less than 20 years after the end of emigration, it appears that Ireland faces the same challenges as her partners in the European Union, and other immigrant-receiving countries around the world. I begin this paper with a review of the lessons that can be drawn from the experiences of other immigrant receiving economies. Labour economists have documented how policy regimes and economic conditions can shape the size and the composition of immigrant inflows. There are also substantial lessons to be drawn from historical research. International migration one hundred years ago was largely unconstrained by formal policy; analyses of past immigrant flows can tell us much about where migration pressure is likely to be most intense, as well as the likely composition of flows over time. 
In light of the key themes emerging from the historical experiences of other countries, I then offer a preliminary examination of recent Irish immigration. Are the new immigrants predominantly skilled or unskilled? Has the shift in immigrant sources led to a decline in skills (and likely earnings capacity) among immigrants? Some evidence has been produced based on the distribution of work permits across sectors and nationality (Ruhs, 2003). I use a recently released OECD database of immigrant education attainment across member states to examine these questions. The information contained in this database, while far from perfect, allows Irish immigrants to be placed in a broader international context.

Evidence on immigrant skills can be brought to bear in identifying key issues in Irish immigration policy. Prior to 2004, most economic migrants would fall into one of two categories. Immigrants from the European Economic Area (EEA) have had unfettered access to the Irish labour market since 1992. Evidence on their educational attainment should tell us something about how Irish immigrants are self-selected under a laissez-faire policy regime. Other economic immigrants to Ireland require a work permit or work visa. ${ }^{2}$ While Ireland appears to have been fairly liberal in issuing permits to employers looking to import workers from abroad, the conditions imposed on permit-holders are quite restrictive. Permits and visas are limited in duration, and tie employees to a particular employer, or in the case of a visa, to a particular occupation. With the accession of ten new countries to the European Union in 2004, the policy regime facing some of Ireland's leading sources of immigrants has seen a major change. Citizens of the accession countries now have free access to the Irish labour market, and there does appear to have been a surge in accession country immigrants since May $12004 .{ }^{3}$ Will accession immigrants swamp the Irish labour market? Are post-accession immigrants likely to resemble pre-accession flows from this region? For continuing immigration from outside of the EEA, the nature of immigration policy will remain important. Is the current orientation towards temporary migration appropriate, or should a scheme favouring permanent migration be considered? Economics theory and evidence from Ireland and around the world can again be marshaled to help select among the alternatives.

The final points considered in this paper are the long-run implications of the broadening of migration into Ireland. While the absolute numbers of immigrants entering Ireland are small, they almost certainly represent the first link in a chain of potential migrants stretching back to the home country. Migration for the purposes of family reunification is likely to follow the arrival of the first generation of economic migrants. How will this affect the skill distribution of the immigrant population and overall conditions in the Irish economy? The paper will conclude with some speculative comments on these issues.

\section{IMMIGRATION AND IMMIGRATION POLICY: ISSUES AND EVIDENCE}

\subsection{Immigration and the host economy}

One of the most debated aspects of immigration is the potential impact on host country economies. If immigration is likely to have a major impact on conditions, identifying the economic aims of immigration policy must be placed near the front of the policy agenda. Economists have presented a range of reasons as to how immigration could impact upon a host economy. One of the classic questions is the impact that immigration might have on the wages and employment of the existing population. If immigration can be treated as a shock to the supply side of the economy, simple economic theory would predict that host country wages and employment would be adversely affected. While the theory is straightforward, identifying the actual impact of immigration on labour markets has proved elusive. Economists have applied a range of techniques to assess the relationship between immigration and conditions in host labour markets, and there is little 
consensus as to whether immigration does have a substantial impact on native outcomes. ${ }^{4}$ Scholars of $19^{\text {th }}$ century migration, however, argue that international migration under laissez-faire conditions had profound effects on economic conditions around the globe. Hatton and Williamson (1998) report that US wages would have been 10-14 percent higher in 1910 in the absence of post-1870 immigration. Work by O'Rourke and Williamson (1999) suggests that the major labour market impacts of migration were felt in the emigrant-sending countries, where migration caused wages to rise rapidly, stimulating convergence with destinations in the New World. Both branches of research stress the potential for distributional effects. O'Rourke and Williamson (1999) argue that the $19^{\text {th }}$ century mass migration of predominantly unskilled labour from Europe to the US increased American inequality, leading to demands for restrictive migration policy. ${ }^{5}$ Whether the divergence between historical and present-day findings is a result of differences in econometric techniques, or differences in the scale of migration, is open to debate. A sensible interpretation may be that migration at rates common in contemporary economies will have moderate effects on receiving labour markets, and substantial effects on labour markets in the origin. Distributional issues, related to the skills of incoming workers in the host economy, will be of critical importance.

Another area of interest is the interaction of immigration and the welfare state. Immigration could prove costly if migrants make disproportionate use of social benefits. On the other hand, an immigration policy that favours the entry of young active workers could reduce dependency ratios in rich economies that feature ageing populations, thus helping to sustain the social safety net in the longer run. Most studies of social assistance recipiency find that immigrants are less likely to take up social assistance than demographically similar natives. The key words, however, are “demographically similar”. If immigrants have lower labour market capacities than native-born workers, they will make disproportionate use of social assistance. Economies in continental Europe have seen rising rates of recipiency accompany declining immigrant skill over the course of the 1990s (Brücker et al., 2001). While immigration can add fresh young workers to an aging population, it is unlikely that immigration can have a substantial impact on dependency ratios. Green and Green (1999) report that a trebling of (disproportionately young) Canadian inflows over a fifty-year period would reduce the proportion of the population over the age of 65 by only 5 percent. As a whole, it appears that so long as immigrants have the skills to succeed in host country labour markets, they are unlikely to have a major impact on the sustainability of the welfare state.

A further argument is that immigrants can fill economic needs not met by the native labour force. This perspective holds that immigration policy can be a useful method to fill occupations in which domestic workers are in short supply, and may also have a role in expanding the human capital endowment of the host economy. ${ }^{6}$ Arguments in favour of migration to fill short-term requirements in the labour force have shaped migration policy on both sides of the Atlantic. Many European economies have operated temporary migration policies to fill "gaps" in domestic labour supply. The employer-driven allocation of work permits in Ireland would appear to work along these lines. Employers are entitled to apply for work permits to fill positions for which suitable candidates who do not require work permits are unavailable. Policies oriented towards permanent migration often reward potential immigrants in categories in high demand, and restrict migration into protected or high-unemployment occupations.

In the context described above, immigration policy is best seen as a potential substitute for education policy, and the relevant question is whether targeted migration is a superior approach to dealing with occupational shortages. In economies where permanent migration policy is the norm, the main shortcomings are that it is difficult to identify what sectors ought to be targeted, and that many immigrants do not enter their intended occupations after migration (Green, 1995). Green 
and Green (1995) document the declining importance of occupational targeting as part of the Canadian point system, while Bauer and Zimmermann (1999) give this difficulty a major role in their argument against the adoption of a point system for European Union countries. As Green and Green (1999) conclude, it is likely that workers "on the ground", be they immigrant or native, will do a better job of targeting high-demand occupations than will a migration policy that is costly to change. ${ }^{7}$ In the case of an employer-led temporary migration policy, immigrants are recruited to direct positions that have not been filled by non-immigrant (or in the Irish case, non-EEA) labour. Immigrants are by definition filling "gaps", but there are reasons to be hesitant regarding this policy orientation. Labour market conditions change over time, meaning that current immigrants may not have skills suited for the "gaps" that emerge in the future. This would is not a major concern if a policy of temporary contracted migration is enforced; today's temporary migrants will return to their homelands upon the expiry of their permits, to be replaced by migrants with skills more suited to the changed conditions in the domestic labour market. The enforcement of return migration is crucial for this policy to succeed; however, empirical evidence from migration regimes around the world suggest that temporary migration tends to transform itself into permanent migration. ${ }^{8}$ If, after accounting for the risk of deportation, labour market opportunities for illegal immigrants (having remained past the expiry of their work permit, without renewal) exceed the opportunities at home, one would expect immigrants to attempt to remain in the host economy. Various schemes have been attempted to enforce the return of temporary immigrants, and most have met with little success. ${ }^{9}$ If temporary migration results in the recruitment of immigrants who are less able to adapt to changing conditions in the host economy, the tendency of these migrants to linger will place additional demands on the welfare state and will likely stimulate anti-immigrant sentiment among the native population.

Other proponents of immigration point to the investment generated by migrants, and the trade links created by migration flows between source and destination economies. The notion that investment and trade will follow the settlement of certain types of immigrants is often used to motivate the recruitment of "investor immigrants." This is a feature of current Irish policy, with business permits being issued to nationals countries outside the EEA and states with Association Agreements who are willing to invest $€ 300,000$ in the establishment of a business in Ireland. Evidence from Canada suggests, however, that while trade and immigration are linked, it appears that the volume of independent immigrants is a better predictor of trade flows than the volume of investor class immigrants (Head and Ries, 1998). While trade does appear to follow the arrival of immigrants, it is likely that there are rapidly diminishing returns to additional flows in this regard (Green and Green, 1997). It is also not evident that investor immigrants will have a substantial marginal effect on inward investment. In economies that are open to international capital flows, the investment that accompanies immigrants will essentially crowd out additional capital imports.

A final consideration would be the possible benefits to having a population with greater diversity. Lazear (2000) argues that gains from trade exist in interactions between individuals of different backgrounds. This theory proposes that individuals of different backgrounds possess different sets of knowledge; the less overlap between the knowledge of interacting individuals, the larger the gains that can be made by the transmission of knowledge through the process of interaction. Gains from diversity imply that a policy of "balanced" immigration is desirable. The model also reminds us of the importance of general human capital: for the gains of diversity to be realised, immigrants and natives with disjoint backgrounds must be able to communicate in a common language. From the perspective of the host economy, immigrants who can speak the local language (or are more likely to rapidly acquire fluency) offer greater potential benefit. 


\subsection{Who migrates?}

Much of the above discussion suggests that the net benefits to be captured by setting an immigration policy to achieve economic aims are largely illusory. This is reflected in recent quantitative studies of prospective migratory scenarios in Europe. ${ }^{10}$ The skills of immigrants, however, do likely matter: if migrants do not possess sufficient general human capital to adjust to conditions in the host economy, the potential costs of immigration are heightened, as are any distributional consequences. Many contemporary studies argue that immigrant skills are closely associated with immigrant origin. Immigration is strictly controlled in most present-day economies through the use of quotas, permits, and other administrative methods, and these tools may play an important role in shaping the origins of the immigrant population. An important question is how large flows would be, and from what destinations, in an environment of laissez-faire migration. An understanding of the determinants of migration in such an environment can help generate informed predictions as to how the international mobility of labour will evolve when migration barriers are reduced. In the Irish context, particular interest is directed at future flows from the accession countries to the European Union, as their nationals now have virtually unfettered access to Irish labour markets.

Evidence from late $19^{\text {th }}$ and early $20^{\text {th }}$ century migration towards the New World offers a long run perspective on the forces driving migratory flows. Hatton and Williamson (1998) model European emigration to the New World between 1860 and 1913. They find that while economic conditions at home and abroad were important determinants of migration flows, demographic factors also have an important role to play. Population growth in the source has a strong impact on future migration in their model, and the size of the emigrant stock abroad plays an important role in reinforcing migration trends over the long run. Economic historians have also used the framework of a gravity model to examine immigration to "open" American labour markets in the late $19^{\text {th }}$ century (for example, Dunlevy and Saba, 1992). One important result in this literature is that distance plays a strong role in determining the size of flows, with source countries closer to the Atlantic seaboard (or in the case of Canada, on the other side of the $49^{\text {th }}$ parallel) supplying more immigrants to the United States, all else equal. These findings are unlikely to surprise many economists, but they can be put to good use in determining the migration potential of source regions. Immigration is more likely to become a flood when the destination is close, an expatriate community already in place, and the source economy replete with young, unattached workers. Emigration is also a self-limiting process; as economic and demographic conditions at home change, demand for migration will attenuate quite rapidly (O'Rourke, 2004).

A second branch of migration research focuses on the nature of immigrant self-selection within source economies. Whether sources supply immigrants from the top or bottom end of their domestic kill distribution will also affect the composition of immigration and the result of any economic calculations as to the attractiveness of migration. What forces are likely to influence the selection of who migrates? Economic theories of individual migration typically treat the decision to emigrate as an investment decision (Sjaastad, 1962). Potential migrants compare the present value of the benefits of migration - the discounted future stream of higher earnings associated with residence and work abroad - with the costs of migration. As identified by Borjas (1987), the benefits to migration may vary across individuals in accordance with their skills. Economies that feature high levels of dispersion in earnings offer better returns to skilled workers, and are predicted to be attractive to skilled migrants originating in source countries with less dispersed earnings. Destinations which feature low-income inequality will prove more attractive to the relatively unskilled who originate in regions with more dispersed earnings. The relationship 
between source country and economic performance has been an area of intense interest to labour economists. Findings from contemporary labour markets suggest that the shift from European sources to developing countries in Latin America, Africa and Asia, has led to declining skill and earnings capacity. (Borjas 1985, 1994; Brücker et al., 2001). Historical evidence is more nuanced; a comparison of "old" and "new" immigrants in the early $20^{\text {th }}$ century United States indicates that the "new" immigrants from southern and eastern Europe had steeper earnings profiles than the "old" immigrants (Minns, 2001). It may be that the crucial element is not the origin of the migrants, but rather the intentions of immigrants once arrived in the source economy. The demographic characteristics of immigrants to North America one hundred years ago are those of economic migrants in search of labour market opportunities; recent migration flows to mature economies feature large numbers of migrants seeking family reunification with relatives already resident in the source country. Economic migrants from developing countries today may have high potential earnings capacity, but this is obscured by increasing non-economic migration from the same place of origin.

\section{A PICTURE OF IRISH IMMIGRANT SKILL}

How can lessons from historical and international evidence help in framing the present day immigration debate in Ireland? We first need to establish the nature of recent migration into Ireland. It is now well known that return migration to Ireland has declined, and that returnees and immigrants from Britain and the United States are being replaced by immigrants from the EEA (as it stood in April 2004) and other sources further afield. Therefore, Irish immigration has quite rapidly begun to shift away from being composed primarily of individuals with some familiarity with customs and institutions in Ireland and the broader anglophone world. Where are the immigrants coming from, and has Ireland been able to attract skilled individuals as part of these flows?

A recently released OECD dataset reports on the size of the stock of immigrants for all member nations in 2002, with this stock further subdivided by country of birth and educational status. ${ }^{11}$ Ideally one would like to have this information for the flow of immigrants into Ireland since 1998, but given the recent nature of the "new" immigration to Ireland, the composition of immigrant stocks from most sources other than the US and UK should be a fairly close match to the underlying flows in the past 5 years. ${ }^{12}$ Evidence on the uptake of work permits is another good indicator of the leading sources of Irish immigrants. These figures are informative regarding the flows of certain types of immigrants from certain destinations, but do not identify EU immigrants or other migrants arriving in Ireland through avenues other than the possession of a work permit. Table 1 lists the top twenty sources of Irish immigrants in 2002. Column (1) lists the stock of immigrants from each source country present in the Census of that year. Columns (2) and (3) offer two measures of the educational attainment of the stock from each source country: the proportion having tertiary education, and the proportion possessing only primary education. Unsurprisingly, Great Britain and the United States head the list of immigrant stocks. While immigrants from the UK are not particularly skilled, the majority of Americans in Ireland have attended college or university. Below these two countries, we see a mix of nearby and distant sources. Anglophone source countries are important, with almost 19,000 immigrants hailing from South Africa, Australia, Canada, and New Zealand. The education data for these origin groups suggest skill levels that are quite similar to those of American immigrants. EU-15 sources also figure prominently, with German, French, Spanish, Italian and Dutch immigrants represented in Table 1. These include considerable numbers of recent arrivals. Of the 27 thousand immigrants from France, Germany, Italy, Spain, and the Netherlands, over 11 thousand (about 40 percent) arrived in Ireland after 1996, with more than half of French, Italian, and Spanish migrants having 
been in Ireland less than 5 years in 2002. EU immigrants can migrate freely to Ireland, and their characteristics give a good picture of the nature of migrant self-selection between Ireland and her neighbours. The message that one would take from this table is that EU immigrants in Ireland are if anything more skilled than their Anglophone counterparts from North America, Oceania, and Southern Africa.

Outside of the (old) EEA and the English-speaking world, three developments can be highlighted. The first is the presence of large numbers of immigrants from Eastern Europe. Russia and Latvia appear on the list in Table 1; Poland, Lithuania, and the Ukraine lie just outside of the top 20. Immigrants from these countries take up a large proportion of the work permits issued in Ireland (especially prior to May 2004). At first glance, Table 1 suggests that there is considerable variance in skills among Central and Eastern European immigrants to Ireland; among Romanian and Latvian immigrants, over 30 percent lack a secondary education. Immigrants from Russia, however, have similar educational attainment to most western European immigrant groups in Ireland. This split across Central and Eastern European source countries persists in those just missing the list in Table 1. Only 35 percent of Polish immigrants and 30 percent of Lithuanian immigrants have third-level qualifications, while the majority of Ukrainian and Belorussian arrivals did. Asian immigrants have made a substantial foothold in Ireland. These immigrants also account for a large proportion of Irish work permits, particularly arrivals from the Philippines and the Indian sub-continent. Over two-thirds of Philippine, Indian, and Pakistani immigrants have a third-level education, while less than fifty percent of Chinese and Malaysian immigrants have the same level of qualifications. Table 1 also confirms the important presence of the Nigerian community in Ireland, who appear to be roughly mid-table in terms of education among immigrants. $^{13}$

The final column in Table 1 lists average educational attainment at home for the twenty source countries under consideration. ${ }^{14} \mathrm{~A}$ quick glance at the figures makes clear that the average education of immigrant populations in Ireland bears little relationship to average educational attainment at home. Among the relatively wealthy countries listed, the best-educated immigrants appear to come from France and Spain, which, by European standards, have low levels of average education at home. Eastern Europeans are on average about as well educated as their counterparts in the West, but it is clear that Ireland has not received as favourable a draw from many of these populations. The figures for Asian immigrant in Table 1 confirms the overall pattern; some groups are highly skilled, others less so, and these differences hold little relationship with average educational attainment at home. The data as a whole suggest that Irish immigrants are predominantly economic migrants, with characteristics shaped by the self-selective nature of flows between particular source countries and Ireland.

\section{NATIONAL ORIGIN AND EDUCATION IN AN INTERNATIONAL CONTEXT}

In Table 2, I extend the analysis of immigrant educational to a subset of fellow European economies. The educational attainment of the Irish "top 20" is compared to immigrants of the same origin in France, Belgium, Spain, and the United Kingdom The reader should use some caution in making comparisons based on Table 2. Self-reported measures of education are often overstated, and whether the qualifications of all immigrants should be treated as equivalent to domestic qualifications is open to debate. The figures presented are also subject to the caveat that there may be important demographic differences between immigrant groups within and across countries. Many European economies have immigrant communities much longer established than those in Ireland, and it is possible that older immigrants have a very different distribution of (relative) skills than do recent arrivals. With these limitations in mind, what can be concluded 
from the numbers on display? Most striking is the evidence that Ireland's immigrants are highly skilled, relative to foreign-born populations in other European economies. For 12 of 20 source countries, the Irish-resident group is has the largest proportion with higher education. Earlier studies (Brücker et al, 2001) have attribute the education profile of Irish immigrants to high skill levels among immigrants originating in the United States, but it is clear from Table 3 that recent years have seen Ireland attract highly-educated immigrants from both high-income and lowincome countries. Caution is required in comparing Ireland's young, recently educated immigrant stock with the more seasoned immigrants of other European economies. However, the bulk of research on European migration suggests that the skills of recent immigrants have declined relative to earlier waves of immigrants, and this is usually thought to reflect the changing composition of the source of immigrants since 1990. In terms of education, there is less evidence of a similar trend accompanying the rise of the "new" immigration in Ireland.

While the above analysis suggests that Irish immigrants are skilled by international standards, some of the relatively large immigrant groups do not appear to be as skilled as the equivalent communities in other European economies. In particular, Ireland does not appear to fare as well in selecting immigrants from Central and Eastern Europe; Irish immigrants from Romania and Latvia are poorly educated relative to those found in other EU economies. As Central and Eastern Europeans have migrated in increasingly large numbers to Ireland since 2002, lower levels of education among this group could lead to an unravelling of the relatively positive picture suggested thus far.

\section{SELF-SELECTION, MIGRATION POLICY, AND IMMIGRANT SKILL}

Recent Irish immigrants are predominantly economic migrants, and as such their skills are unrepresentative of "average" skill levels at home. The evidence on education suggests that there is little reason to presume that the potential fortunes of the immigrant population will decline as the primary source for immigrants shift from countries with high average skill levels to countries with low average skill levels. This does not imply, however, that economic conditions at home and abroad are unimportant in shaping the character of immigrant flows between Ireland and particular source countries. The structure of earnings in Ireland relative to the source country may be important determinant of immigrant skill levels. Migration choices are also constrained by immigration policy. In this section, I assess what can be learnt through an examination of the skill composition of immigrant flows entering Ireland under different policy environments.

\subsection{EEA immigration}

Immigrants from the European Economic Area have had free access to Irish labour markets since 1992. Therefore, their migration decision are a true test of self-selection; no policy is in place to limit intake to the highly skilled or those who have established contact with particular employers. Given freedom of movement between Ireland and the rest of the EU, it is likely that the returns to skill play an important role in determining who chooses to locate in Ireland. Can the self-selection hypothesis espoused by Borjas (1987) explain the patterns of labour mobility within the EU? Pane A of Table 2 lists the ratio of incomes at the $90^{\text {th }}$ and $10^{\text {th }}$ percentiles for a selection of EU states. ${ }^{15}$ This measure of income inequality can be interpreted as a rough proxy for the returns to skills across the countries. These data suggest that Ireland is near the top of the EU on this measure, and well above most continental members. When absolute levels of income are considered, Nolan and Smeeding (2004) estimate that the gap between the top and bottom ten percent in Ireland is equal to \$32,473 US dollars at 2000 PPP, compared to $\$ 29,960$ for the UK, $\$ 22,510$ for the Netherlands, and \$21,830 for Germany. That Ireland leads the European table of 
income inequality is quite possibly an undesirable policy outcome, but the implications for migration, particularly within the EU, are important. High returns to skill in Ireland appear to have attracted highly educated immigrants from continental Europe. These flows may have served to dampen further rises in inequality, much as the return of skilled expatriate Irish in the early 1990s are thought to have had a similar effect (Barret, FitzGerald, and Nolan, 2002).

\subsection{Non-EEA immigration}

In the Irish case, economic migrants who do not possess EEA passports require a work permit or work visa to participate in the Irish labour market. Work permits, for which the employer makes the application, legitimise the work relationship between a particular employer and employee. For a permit to be granted, the employer must establish that they have been unable to fill the employment position with an individual who does not require similar authorization. ${ }^{16}$ Immigrants who enter Ireland on this basis do not have the opportunity to search for employment that better matches their skills. These permits are usually granted for a period of 12 months, and work permit holder are not entitled to state-funded medical care, education, or social welfare. The work permit scheme has recently been complemented by a work visa and work authorisation scheme. Since 2000, potential employees in sectors featuring labour shortages having secured a job offer in Ireland can receive employment clearance before immigrating to Ireland. ${ }^{17}$ Work visas are granted for a two-year period, and holders of these permits are allowed to change employers, so long as they remain in the same occupational class. While holders of these visas do not have the right to state-funded medical care, education, or social welfare, they may be accompanied by spouses and dependent children, with minors under the age of 18 being eligible for state-funded primary and secondary education. ${ }^{18}$

Table 4 provides a statistical overview of the recipients of work permits in Ireland. The first three columns lists the number of work permits issued to national groups in the years between 2002 and 2004. Columns four and five summarize the proportion of immigrants from each source region with third-level education in Ireland and across the entire OECD. Where Ireland appears to have done particularly well in attracted highly educated immigrants is from countries with strong Anglophone traditions (due to being colonies of either Great Britain or the United States) in the developing world. In particular, consider the case of immigrants from the Philippines, India, and Pakistan. It is likely that there is a relatively larger pool of skilled workers from these countries who are fluent in English than is the case among their counterparts in South America or Eastern Europe. The employer-led permit system would also facilitate the recruitment of skilled labour from these countries; English-speaking recruiters can verify credentials at lower cost than in economies that do not have the same extent of Anglophone traditions. Skilled workers from Central and Eastern Europe may be more attracted to migration possibilities offered on a permanent basis. In the Canadian case, for example, a match with an employer is not required prior to migration, which means that immigrants can concentrate on investing in host-country specific human capital before beginning an employment relationship. The OECD data on immigrant education supports this hypothesis. The percentage of the Canadian adult immigrant stock with third-level education from the former Soviet Union (49), Romania (54), Latvia (40), Lithuania (32), and Poland (35) match or exceed the figures for the same stocks in Ireland. ${ }^{19}$ Brazilian immigrants in Canada are also more likely to have some college or university training than their Irish counterparts (49 percent versus 25). Once again, these comparisons must be interpreted carefully, as demographic differences between these groups will are likely related to educational attainment. At first glance, however, the comparison suggests that a policy of permanent migration (complemented by a points system, as discussed in more detail below) may 
be more effective in attracting immigrants with higher levels of general human capital who lack host-country specific human capital.

Table 5 lists the distribution of work permits by occupation for leading sources of Irish immigrants. Anglophone immigrants from Australia, Canada, New Zealand, and the United States are concentrated in professional-type occupations, with weekly wages ranging from $€ 750$ to $€ 1200$ in 2002. ${ }^{20}$ Asian immigrants also have substantial presence in the top end of the occupational distribution, but personal and protective service emerges and a dominant category in many cases. This is an extremely heterogeneous category, as it includes workers engaged in domestic service, with weekly wages of about $€ 250$, catering employees, as well as nursing and other medical serviced, where weekly wages are over €700. Eastern European migrants are much more concentrated in agriculture, "other services, and "other" occupations, where weekly pay tends to be in the order of $€ 280$ to $€ 350$. These figures present a much less flattering portrait of immigrants entering under permit than do the data on education. The educational qualifications many of these groups would suggest greater earnings capacity than the typical wage offers received by permit holders. A possible explanation is that despite the limitations imposed by the Irish permit system, relatively well-educated immigrants are willing to engage in service employment in order to gain a foothold in the Irish labour market. Immigrants may arrive in Ireland on an initial permit under the expectation that they will be able to obtain a better match upon its expiry if they are "on the ground" in Ireland to search for future employment.

\section{IMMIGRATION AND THE FUTURE}

\subsection{Accession and immigration}

Prior to 2004, economic migrants from Eastern European would require work permits or visas. A substantial number of permit-holding European migrants were from the ten accession countries. How will migration from these sources be changes with the accession of these states to the European Union? The first question that might be asked is whether accession is likely to trigger a flood of immigrants from these states. While preliminary evidence on the uptake of PPS numbers suggests that accession country migrants have been coming to Ireland in increasing numbers since May 1 2004, geography and demographics suggest that a "flood" of migrants to Ireland from these countries is unlikely. One reason is that there are major European economies much closer to most of the accession countries - in particular, Germany, which already has substantial communities of migrants from these countries. Distance from home, and the size of the expatriate community in the destination, remains important determinant of the size of immigrant flows. Another reason is that the demographics of the accession countries do not favour mass migration to richer markets in the EU. The demographic structure of the accession countries is very much like that of their new European partners. In Ireland, 24 percent of the population is aged between 20 and 34, which are often through to be prime ages for potential emigration. In Germany, the largest EU economy, the corresponding figure is 19 percent. For Latvia, Lithuania, and Poland, accession countries which dominate recent flows into Ireland, the proportions aged 20 to 34 are 21, 20, and 23 percent. A temporary rise in migration post-accession from these countries is likely as they become better integrated into the wider European economy, but there seems little reason to suspect that accession will release a raging stream of pent-up potential immigrants.

How will accession affect the skill composition of Irish immigrants? If one were to project based on the skills of the stock in 2002, increasing migration from accession countries would be predicted to drive down the average skills (and presumed earnings capacity) of the immigrant population, a trend that would exacerbate income inequality and perhaps encourage developing 
anti-immigrant sentiment. However, evidence for existing EU immigrants suggests that this is not the most likely development. Now that immigrants from the accession countries can freely selfselect migration to the EU, theory would predict that Ireland will attract the highly-skilled, as it has from existing EU member states. Self-selection theory would predict this outcome, as income inequality in Ireland exceeds that in most of the accession countries. Panel B of Table 3 lists decile ratios for a sample of EU accession states. With the exception of Estonia, where language ties make Finland a major immigrant destination, these are well below the ratio reported in Ireland (panel A). ${ }^{21}$ This prediction is subject to the caveat that the impact of accession on the distribution of incomes in the accession countries is unknown. If inequality increases as a consequence, the incentives to migrate to Ireland would likely shift as well.

\subsection{Permits or permanence?}

The current system of admitting immigrants to Ireland is one that encourages temporary, rather than permanent migration. Is it likely that this system is to prove the most desirable in the longer run? A temporary policy seems attractive if one is interested primarily in remedying labour shortages, and wishes to avoid the potential costs of changing ethnicity associated with permanent migration. Consider, however, the earlier discussion regarding the economics of immigration policy. Temporary migration is unlikely to remain temporary, so long as economic conditions in Ireland are attractive to potential immigrants. Even if the individual immigrants currently in Ireland on permits were to return home, the "friends and family" effect will likely operate through the information about Irish institutions and conditions that they would take back to their home economies. This will spawn future demand for migration to Ireland, be it through the permit system or through illegal employment on the black market.

The potential benefits and distributional consequences of immigration are linked to the skills of migrants. An important question, therefore, is how permanent and temporary migration policies may influence the self-selection of workers who wish to reside in Ireland. The evidence suggests that potential permanent immigrants from EEA economies are highly educated, while immigrants arriving through the permit regime are more mixed. It is plausible that contracted temporary migration, at least under the restrictive regime imposed in Ireland, may be unappealing to some workers with high levels of general human capital. The restrictions placed on immigrants' ability to search for employment once in Ireland provides employers with a degree of monopsony power over their immigrant work force. If immigrants with high levels of general human capital sacrifice much of the return to their skills if they are unable to complement their pre-migration human capital with post-migration job search, flows may be diverted towards less skilled immigrants with less to sacrifice in terms of potential earnings. It is hard to see how a policy that restricts immigrants from outside the expanded EEA into the full set of opportunities available in the Irish labour market is likely to enhance the selection of skills among arriving immigrants. Low unemployment and high returns to skill currently make Ireland attractive to skilled migrants from around the world, but this situation will change as the relative labour market conditions in Ireland evolve in the future. At the very least, a policy allowing temporary migrants longer spells in the Irish economy and more latitude in searching for employment would make Ireland more attractive to those with general skills, and would reduce the potential for employers to extract monopsony profits from their immigrant work force.

One might also question whether temporary contracted migration of low-skilled workers is desirable over the longer run. These immigrants may fill short-run shortages in the supply of unskilled labour, but they are likely to have difficulty adapting to changing labour market conditions should they remain permanently in Ireland. Ample evidence exists that temporary migrants are less likely to invest in host country specific human capital than individuals intending 
to migrate on a permanent basis. ${ }^{22}$ This points to the potential emergence of a vicious cycle: the permanent settlement of what were intended to be temporary immigrants is unlikely to be wellreceived by the domestic population, particularly if they do not adjust well into Irish labour market over the longer run. A hardening of Irish attitudes towards migration would lead to demand for greater restrictions, and the benefits of greater ethnic diversity would be lost. ${ }^{23}$

If Ireland were to move towards a migration policy favouring permanent migration, what options ought to be considered? One possibility is the introduction of a points system, as currently in place in Canada, Australia, and New Zealand. A point system selects immigrants on the basis of characteristics associated with likely success in the host country labour market. In the Canadian case, immigrants with a minimum of one year of work experience in managerial, professional, and skilled technical occupations are eligible to apply for entry as independent immigrants. The majority of points are awarded predominantly for general human capital characteristics: education, language ability, labour market experience, and age. Additional points are allocated to arranged employment and "adaptability", which reflects past employment and contacts in Canada, the education of the spouse of an immigrant, and previous employment experience in Canada. ${ }^{24}$

The virtue of a points system is it can be used to screen out a pool of suitably skilled immigrants from the population of potential immigrants. The number of immigrants admitted from this pool can be varied from year to year, depending on current conditions in the domestic labour market. The virtues of the point system have also stood up to empirical scrutiny. Borjas (1990) identifies the presence of a point system as one reason for which Canadian immigrants since the 1960s have been more skilled than their American counterparts. Green and Green (1995) also find that the introduction of the points system has helped slant the Canadian immigrant population towards higher levels of skill. The introduction of a points system would seem a good way to select highly educated and adaptable immigrant for potential permanent migration to Ireland.

\subsection{Immigration and the Irish population in the longer run}

This paper's review of Irish immigrant skills suggests that Ireland has had the fortune to mainly attract skilled economic migrants. The message one can take from the analysis above is that this should be expected to continue to continue in the near future, perhaps with some assistance from the introduction of a points-type system. The permanent settlement of economic migrants will, however, in due course lead to increasing levels of non-economic migration. The "friends and family effect" will lead to demand for family reunification following initial permanent settlement. In some sense this is unavoidable; countries might wish to limit migration by operating policies of contracted temporary migration, but these flows are unlikely to remain temporary so long as labour market conditions in Ireland are attractive. A policy that spells out the legal rights of permanent immigrants in this regard is no doubt preferable to a situation in which illegal or semilegal temporary migrants in Ireland attempt to smuggle in family members as tourists and the like. This will likely have an impact on the skills of Irish immigrants. Family migrants are not likely to be self-selected in the same way as economic migrants. Borjas and Bronars (1991) suggest that in the case of sequential family migration, members who benefit most from potential migration will be the first movers, with less suited family members to follow. Empirical evidence from North America tends to support this perspective. Green and Green (1995) report that while the points system is highly effective on the margin, its overall impact on immigrant skill level is muted by growing numbers of non-economic migrants. While the evidence listed in Table 1 suggests little relationship between immigrant education and average education in the source country among Irish migrants, this presumption may not hold once family reunification becomes an important source of immigrants. In the longer run, the average educational attainment of source countries 
may become a more important predictor of the characteristics of the Irish immigrant population. In the medium term, this is likely to have a modest effect on immigrant skills; European countries dominate Irish immigrant stocks, and be they in the EU, the accession states, or further east, these sources have relatively high levels of average education. In the longer run, inflows of economic migrants from developing countries outside of Europe will be joined by family. Current schooling levels in these source countries are below the European norm; if this continues to be the case, immigrant skills are likely to decline. This does not mean that Ireland ought to limit access to family reunification in preparation for this possibility. The morality of denying current Irish immigrants from developing countries the possibility to bring their families to Ireland, while many less-skilled European immigrants will do so, is questionable at best. It is also likely that if the first generation of these immigrants are highly skilled and well integrated in the Irish economy, this will lead to positive spillover effects that will ease the assimilation of later generation of immigrants. Better adjusted (permanent) immigrants today will enhance the prospects for successive generations.

\section{CONCLUSIONS}

Immigration is at the heart of major policy debates in most of the world's leading economies. Ireland is no longer exempt for this debate, as prosperity has led to significant migration of overseas immigrants into Ireland. What should be the objectives of Irish immigration policy? While there is little evidence that immigration has a large impact on wages and employment in contemporary labour markets, it is also unlikely that immigration is a highly effective solution to economic problems such as short-run labour shortages, an aging population, or the attraction of foreign investment. Some benefits may flow from the promotion of trade or the increased diversity of the domestic population. Policy can play an important role, however, in shaping the selection of migrants that enter Ireland. Policies geared towards the admission of skilled economic migrants are likely to enhance any benefits that do flow from immigration. They are also likely to result in an immigrant community that adapts well to labour market conditions in Ireland and enhances the reputation of the foreign-born among the native-born population. Evidence on education suggests that Ireland has mainly attracted skilled immigrants as part of recent inflows. Immigrants from within the EEA are highly educated, a pattern that appears to the self-selection theory developed by Borjas (1987). Outside of the EEA, the evidence is more mixed. While about 75 percent of work permit holders are contracted to work in unskilled occupations, data on education suggests that many source countries outside of the EEA are supplying Ireland with highly qualified immigrants. This would appear to be due to the economic conditions that prevail in Ireland, rather than a result of the policy regime that selects immigrants. High returns to skill in Ireland are attractive to educated immigrants, who may be willing to enter Ireland in unskilled employment with the intention of moving up the job ladder in subsequent years. What policy alternatives need to be considered for the future? One option is the development of a policy regime that encourages the immigration of skilled individuals on a permanent basis. A substantial share of today's temporary immigrants will establish a permanent foothold in Ireland. The current policy, which favours the employer-led recruitment of foreign labour into mainly unskilled employment, is unlikely to enhance the skills level of the Irish immigrant population in the longer run. A permanent migration policy that offers immigrants the same rights in the Irish labour market as EEA nationals will enhance the economic assimilation of Irish immigrants, and will expand the benefits associated with trade and diversity. A points system that selects immigrants on the basis of general human capital characteristics has proved an effective device to select economic migrates who are likely to adapt well in the host economy. Finally, it should be noted that noneconomic migration is likely to grow in importance in Ireland. Parts of these flows consist of refugees and asylum seekers arriving in Ireland for humanitarian reasons. They will soon be 
joined by immigrants seeking family reunification with relatives who have already established themselves in Ireland. While family migrants are unlikely to be self-selected in the same way as earlier economic migrants, it will provide difficult to justify their exclusion from the state. Once again, a sensible policy would appear to be one that allows for the permanent migration of skilled economic migrants. Well integrated first-generation immigrant arrivals enhance the economic prospects of those that follow. 


\section{References}

Barrett, Alan (1999) "Irish migration: characteristics, causes, and consequences." IZA discussion paper 97.

Barrett, Alan, John FitzGerald and Brian Nolan (2000) "Earnings inequality, returns to education, and immigration into Ireland.” Labour economics, 95 665-680.

Barrett, Alan and F. Trace (1998) "Who is coming back? The educational profile of returning migrants in the 1990s.” Irish banking review, Summer.

Barro, Robert J. and Jong-Wha Lee (2000) "International Data on Educational Attainment: Updates and Implications.” CID Working Paper no. 42.

Bauer, Thomas, and Klaus F. Zimmerman (1999) “Assessment of possible migration pressure and its labour market impact following EU enlargement to Central and Eastern Europe.” IZA Research Report 3.

Borjas, George J. (1985) "Assimilation, changes in cohort quality, and the earnings of immigrants.” Journal of labor economics, 34, 463-489.

Borjas, George J. (1987) “The self-selection of immigrants.” American economic review, 774, 531-555.

Borjas, George J. (1993) "Immigration policy, national origin and immigrant skills: a comparison of Canada and the United States," in Small differences that matter: labor markets and income maintenance in Canada and the United States, eds. David Card and Richard Freeman. Chicago: NBER.

Borjas, George J. (1994) “The economics of immigration.” Journal of economic literature, 334 1667-1717.

Borjas, George J. (1995) “The economic benefits from immigration.” Journal of economic perspectives, 92, 3-22.

Borjas, George J. (1999)b. Heaven's door: immigration policy and the American economy. Princeton NJ: Princeton U Press.

Borjas, George J. (2003) "The labor demand curve is downward sloping: reexamining the impact of immigration on the labor market.” Quarterly journal of economics, 1184 1335-1376.

Borjas, George J, and Stephen Bronars (1991) "Immigration and the family." Journal of labor economics, 92, 123-148.

Brücker, Herbert, Gil S. Epstein, Barry McCormick, Gilles Saint-Paul, Alessandra Venturini and Klaus Zimmermann (2002) "Managing migration in the European welfare state," in Immigration policy and the welfare system, eds Tito Boeri, Gordon Hanson, and Barry McCormick. Oxford: OUP.

Cairnes, J. E. (1873) Political essays. London: MacMillan.

Central Statistics Office (2004) Population and migration estimates. Dublin: CSO. 
Dumont, Jean-Christophe, and Georges Lemaître (2003) "Counting immigrants and expatriates in OECD countries: a new perspective.” OECD Social, employment, and migration working paper.

Dunlevy, James A. and Richard Saba (1992) "The role of nationality-specific characteristics on the settlement patterns of late $19^{\text {th }}$ century immigrants” Explorations in economic history, 292 228-249.

Dustmann, Christian (1999) “Temporary migration, human capital, and language fluency of migrants.” Scandinavian journal of economics, 1012, 297-314.

Epstein, Gil S., Arye L. Hillman, and Avi Weiss (1999) “Creating illegal immigrants.” Journal of population economics, 121, 3-21.

Friedberg, Rachel M. and Jennifer Hunt (1995) “The impact of immigrants on host country wages, employment, and growth.” Journal of economic perspectives, 92, 23-44.

Goldin, Claudia (1994) "The political economy of immigration restriction in the United States, 1890 to 1921,” in C. Goldin and G. D. Libecap eds., The regulated economy: a historical approach to political economy. Chicago: Chicago University Press.

Green, Alan G. and David Green (1995) "Canadian immigration policy: the effectiveness of the points system and other instruments.” Canadian journal of economics, 284b, 1006-41.

Green, Alan G., and David Green (1999) “The economic goals of Canada's immigration policy: past and present.” Canadian public policy, 254, 425-451.

Green, David A. (1995) "Intended and actual occupations of immigrants," in Diminishing returns: the economics of Canada's recent immigration policy, ed. D.J. DeVoretz. Toronto: C.D. Howe Institute.

Hatton, Timothy J. (1995) “A model of UK emigration, 1870-1913.” Review of economics and statistics, 773, 407-415

Hatton, Timothy J. and Jeffery G. Williamson (1998) The age of mass migration. Oxford: OUP.

Head, Keith and J. Ries (1998) "Immigration and trade creation: econometric evidence from Canada.” Canadian journal of economics, 311, 47-62.

Immigration Council of Ireland (2003) Labour migration into Ireland. Dublin: ICI.

Lazear, Edward, P. (2000) "Diversity and immigration," in Issues in the economics of immigration, ed. George J. Borjas. Chicago: NBER.

Minns, Chris (2000) "Income, cohort effects, and occupational mobility: a new look at immigration to the United States at the turn of the $20^{\text {th }}$ century." Explorations in economic history, 374, 326-350.

Nolan, Brian and Timothy M. Smeeding (2004) "Ireland's income distribution in comparative perspective.” Luxembourg Income Study, working paper 395. 
Ó Gráda, Cormac, and Kevin H. O'Rourke (1997) “Immigration as disaster relief.” European review of economic history, 11, 3-26.

OECD (2003) Database on immigrants and expatriates. Paris: OECD.

O'Rourke, Kevin H. (2004)“The era of free migration: lessons for today.” IIIS Discussion paper 18.

Ruhs, Martin (2003) "Emerging trends and patterns in the immigration and employment of nonEU nationals in Ireland: what the data reveal." The Policy Institute at Trinity College Dublin, working paper 6.

Sjaastad, Larry (1962) "The costs and returns of human migration” Journal of political economy, 705, part 2, S80-S93.

Voth, Hans-Joachim (2003) "Living standards during the industrial revolution: an economist's guide.” American economic review papers and proceedings, 932, 221-226.

Walsh, Brendan M. (1974) "Expectations, information, and human migration: specifying an econometric model of Irish migration to Britain.” Journal of regional science, 141, 107-120. 


\section{APPENDIX}

Table 1: Irish immigrant stock and educational attainment, 2002

\begin{tabular}{|c|c|c|c|c|}
\hline Source country & Stock, 2002 & $\begin{array}{c}\text { Proportion } \\
\text { tertiary } \\
\text { education }\end{array}$ & $\begin{array}{c}\text { Proportion } \\
\text { primary } \\
\text { education only }\end{array}$ & $\begin{array}{c}\text { Average years } \\
\text { of schooling in } \\
\text { source, } 2000\end{array}$ \\
\hline United Kingdom & 248515 & .34 & .37 & 9.4 \\
\hline United States & 21541 & .59 & .17 & 12.1 \\
\hline Nigeria & 9225 & .51 & .19 & \\
\hline Germany & 8770 & .50 & .15 & 10.2 \\
\hline France & 6815 & .70 & .06 & 7.9 \\
\hline South Africa & 6260 & .56 & .11 & 6.1 \\
\hline Australia & 6107 & .56 & .14 & 10.9 \\
\hline Romania & 5838 & .28 & .31 & 9.5 \\
\hline China (PR) & 5669 & .46 & .17 & 6.4 \\
\hline Spain & 4632 & .71 & .08 & 7.3 \\
\hline Philippines & 4086 & .83 & .06 & 8.2 \\
\hline Canada & 4081 & .59 & .15 & 11.6 \\
\hline Italy & 3705 & .48 & .24 & 7.2 \\
\hline Netherlands & 3512 & .54 & .14 & 9.4 \\
\hline India & 3402 & .73 & .11 & 5.1 \\
\hline Pakistan & 3391 & .68 & .17 & 3.9 \\
\hline Russia & 2556 & .61 & .12 & 10.0 (“USSR”) \\
\hline Latvia & 2281 & .22 & .18 & 9.5 \\
\hline New Zealand & 2256 & .61 & .09 & 11.7 \\
\hline Malaysia & 2195 & .48 & .20 & 6.8 \\
\hline
\end{tabular}

Source: Immigrant stocks and education are from OECD (2003). Source country education data is from Barro and Lee (2000). 
Table 2: Immigrant education around Europe

\begin{tabular}{|c|c|c|c|c|c|}
\hline \multirow[t]{2}{*}{ Source Country } & \multicolumn{5}{|c|}{ Host Country } \\
\hline & France & Belgium & Spain & $\begin{array}{c}\text { United } \\
\text { Kingdom }\end{array}$ & Ireland \\
\hline United Kingdom & .50 [76423] & $.43[23390]$ & .26 [91560] & --- & .34 [207320] \\
\hline United States & .62 [32321] & .58 [10594] & .53 [15310] & .60 [126482] & .59 [14609] \\
\hline Nigeria & .44 [2491] & .36 [1460] & .13 [8289] & .57 [79880] & .51 [7355] \\
\hline Germany & .29 [198297] & .25 [73442] & .28 [131927] & .31 [231332] & $.50[7622]$ \\
\hline France & --- & .20 [141904] & .28 [140394] & .60 [85179] & .70 [6161] \\
\hline South Africa & .42 [2875] & .40 [2269] & .38 [1172] & .47 [124658] & .56 [5029] \\
\hline Australia & .48 [3656] & .48 [926] & .34 [3467] & .54 [96889] & .56 [4377] \\
\hline Romania & .47 [21997] & .43 [6244] & .13 [50910] & .56 [6662] & .28 [4388] \\
\hline China (PR) & .25 [31334] & .31 [6019] & .10 [24312] & $.47[47850]$ & .46 [5497] \\
\hline Spain & .09 [336699] & .15 [35548] & --- & .45 [50337] & $.71[4391]$ \\
\hline Philippines & .30 [5870] & .27 [5057] & .20 [15987] & .51 [38069] & .83 [3926] \\
\hline Canada & .52 [16179] & .45 [3547] & .47 [3282] & .48 [66858] & .59 [3332] \\
\hline Italy & .07 [403547] & .07 [129908] & .34 [22777] & .27 [103466] & .48 [3469] \\
\hline Netherlands & $.45[26006]$ & .25 [89317] & .32 [20068] & .51 [35043] & .54 [2903] \\
\hline India & .21 [26403] & .28 [7935] & .17 [7067] & .33 [454501] & .73 [3113] \\
\hline Pakistan & .11 [10813] & .17 [3954] & .08 [9426] & .19 [301892] & .68 [2791] \\
\hline Russia & .48 [15738] & $.41[9444]^{\mathrm{a}}$ & .36 [10543] & .67 [13281] & .61 [1959] \\
\hline Latvia & .39 [749] & $.40[132]^{\mathrm{a}}$ & .23 [435] & .36 [4070] & .22 [2182] \\
\hline New Zealand & .57 [885] & $.47[271]$ & .57 [272] & .55 [54608] & .61 [1996] \\
\hline Malaysia & .37 [1369] & .34 [416] & .30 [198] & $.54[47470]$ & .48 [2195] \\
\hline \multirow[t]{2}{*}{ Native population } & .17 & .23 & .19 & .20 & .23 \\
\hline & [52.7 mil] & [9.2 mil] & [38.7 mil] & [53.9 mil] & [3.5 mil] \\
\hline
\end{tabular}

\footnotetext{
Notes: Listed is the proportion of the immigrant stock in each country with third-level education. Number of observations (the size of the stock) is in square brackets.

a - The Russian figure for Belgium corresponds to immigrants recorded as being from the former USSR. The Latvian figure should also be regarded with caution, as a proportion of actual Latvians are likely to be included in the USSR category

Source: OECD (2003)
} 
Table 3: Income inequality in EU and accession states

\begin{tabular}{lc|lc}
\hline & A-EU states & \multicolumn{2}{c}{ B-Accession states } \\
Country & P90/P10 & Country & P90/P10 \\
\hline Netherlands & 2.98 & Slovak Republic & 2.88 \\
Germany & 3.18 & Czech Republic & 3.01 \\
France & 3.54 & Hungary & 3.57 \\
Spain & 3.96 & Poland & 3.59 \\
Italy & 4.33 & Estonia & 5.08 \\
Ireland & $\mathbf{4 . 5 7}$ & & \\
UK & 4.58 & & \\
\hline
\end{tabular}

Source: Nolan and Smeeding (2004). 
Table 4: Work permits and education among Irish immigrants

\begin{tabular}{|c|c|c|c|c|c|}
\hline Country & Permits, 2002 & Permits, 2003 & Permits, 2004 & $\begin{array}{l}\text { Proportion tertiary } \\
\text { education, Ireland }\end{array}$ & $\begin{array}{l}\text { Proportion tertiary } \\
\text { education, OECD }\end{array}$ \\
\hline Philippines & 3255 & 4042 & 4301 & .83 & .48 \\
\hline Ukraine & 2092 & 2866 & 2137 & .50 & .28 \\
\hline Romania & 2459 & 2527 & 2113 & .28 & .27 \\
\hline South Africa & 2273 & 2468 & 2031 & .55 & .51 \\
\hline Poland & 3142 & 4808 & 1915 & .35 & .27 \\
\hline Brazil & 1327 & 1554 & 1512 & .25 & .28 \\
\hline Latvia & 3985 & 4160 & 1363 & .22 & .41 \\
\hline China & 1236 & 1593 & 1284 & .46 & .40 \\
\hline India & 845 & 1030 & 1253 & .73 & .54 \\
\hline Lithuania & 3816 & 4551 & 1238 & .30 & .23 \\
\hline Turkey & 155 & 466 & 1191 & .45 & .07 \\
\hline Bangladesh & 767 & 1038 & 1009 & .48 & .29 \\
\hline United States & 792 & 961 & 927 & .59 & .51 \\
\hline Australia & 1116 & 1149 & 908 & .56 & .47 \\
\hline Malaysia & 1086 & 1030 & 886 & .48 & .53 \\
\hline Pakistan & 840 & 830 & 846 & .68 & .32 \\
\hline Russia & 1238 & 1091 & 795 & .61 & .44 \\
\hline Belarus & 870 & 1028 & 760 & .61 & .25 \\
\hline New Zealand & 569 & 658 & 550 & .61 & .45 \\
\hline Nigeria & 87 & 84 & 60 & .51 & .57 \\
\hline
\end{tabular}

Source: DETE, OECD (2003). 
Table 5: Work permits by nationality and occupation, 2002

\begin{tabular}{|c|c|c|c|c|c|c|c|c|c|}
\hline $\begin{array}{l}\text { Source } \\
\text { country }\end{array}$ & $\begin{array}{c}\text { Permits, } \\
\text { Feb-Dec } \\
2002\end{array}$ & $\begin{array}{c}\% \\
\text { profess- } \\
\text { sional }\end{array}$ & $\%$ clerical & $\begin{array}{c}\% \text { personal } \\
\text { service }\end{array}$ & $\begin{array}{c}\% \\
\text { sales }\end{array}$ & $\begin{array}{l}\text { \% other } \\
\text { sales, } \\
\text { service }\end{array}$ & $\begin{array}{l}\text { \% craft, } \\
\text { operative }\end{array}$ & $\begin{array}{c}\% \text { other } \\
\text { agriculture }\end{array}$ & $\%$ other \\
\hline Belarus & 818 & 3 & 1 & 16 & 11 & 22 & 13 & 19 & 16 \\
\hline Latvia & 3621 & 1 & .3 & 11 & 2 & 18 & 14 & 31 & 24 \\
\hline Lithuania & 3563 & 2 & 1 & 13 & 3 & 20 & 16 & 22 & 24 \\
\hline Russia & 1084 & 15 & 2 & 13 & 4 & 16 & 17 & 12 & 22 \\
\hline Ukraine & 1950 & 2 & .3 & 10 & 1 & 16 & 15 & 31 & 24 \\
\hline Poland & 2921 & 11 & 1 & 9 & 1 & 14 & 34 & 8 & 30 \\
\hline Romania & 2316 & 5 & 1 & 24 & 1 & 20 & 16 & 11 & 24 \\
\hline Turkey & 137 & 13 & 1 & 35 & 3 & 12 & 18 & 4 & 16 \\
\hline Australia & 998 & 60 & 6 & 9 & 3 & 5 & 6 & 2 & 9 \\
\hline $\begin{array}{l}\text { New } \\
\text { Zealand }\end{array}$ & 485 & 54 & 6 & 10 & 1 & 4 & 12 & 3 & 11 \\
\hline USA & 717 & 56 & 4 & 11 & 3 & 4 & 4 & 1 & 9 \\
\hline Bangladesh & 733 & 4 & 1 & 50 & 1 & 27 & 6 & 1 & 11 \\
\hline China & 1145 & 12 & 1 & 49 & 1 & 14 & 14 & 2 & 8 \\
\hline India & 751 & 39 & 1 & 36 & 2 & 6 & 7 & .3 & 9 \\
\hline Malaysia & 974 & 28 & 1 & 51 & 1 & 14 & 1 & --- & 3 \\
\hline Pakistan & 751 & 19 & 1 & 34 & 5 & 11 & 17 & 2 & 15 \\
\hline Philippines & 2989 & 4 & 1 & 53 & 2 & 16 & 7 & 1 & 14 \\
\hline Brazil & 1274 & 3 & 1 & 3 & 1 & 10 & 54 & 4 & 26 \\
\hline South Africa & 2094 & 35 & 3 & 19 & 6 & 13 & 12 & 2 & 10 \\
\hline
\end{tabular}

Source: Ruhs (2003).

Notes: Professional occupations include those defined as "managerial, professional. And associate professional or technical” in Ruhs (2004). Personal service is the "personal and protective service” category, and craft and operative combines these two categories from the original source. Information on the occupation of permit holders is only available from February 2002 onwards. Row totals may not add up to 100 due to rounding. 


\section{Endnotes}

${ }^{1}$ Positive net immigration also occurred in the 1970s, as expatriate Irish returned to Ireland in response to improved economic conditions. (Barrett, 1999)

${ }^{2}$ Ireland is also beginning to receive substantial numbers of non-economic migrants. About 48 thousand applications for asylum were processed between 1999 and 2003 . Student visas are another source of immigrants to Ireland. There is some debate as to whether student immigrants are motivated by economic conditions or the desire to enter the Irish labour market. Non-EEA student visas currently allow the holder to work for up to 20 hours a week, a more generous entitlement than in many other immigrant receiving economies.

${ }^{3}$ These immigrants are restricted, however, in their access to state-funded social benefits.

${ }^{4}$ Friedberg and Hunt (1995) surveys the literature as of the mid-1990s. A recent study by Borjas (2003), however, offers convincing evidence that immigration-induced increases in labour supply do have substantial effects on wages.

${ }^{5}$ Goldin (1994) outlines the link between migration and the emergence of restrictive immigration policies in the late $19^{\text {th }}$ and early $20^{\text {th }}$ centuries.

${ }^{6}$ A related argument, though one I will not examine in great detail here, is that national economies may feature increasing returns to scale. Some scholars argue that greater population size promotes innovation, and thus immigration can lead to enhanced productivity. While the link between population size and productivity growth is a key assumption in recent theoretical models of the long-run transition from economic stagnation to sustained growth, there is little historical evidence to support this view. (Voth, 2003)

${ }^{7}$ Another style of analysis, as seen in Borjas (1995), considers an economy characterised by a production function in which skilled labour, unskilled labour, and capital are employed as factors of production. This model suggests that the "surplus" from immigration, will be larger if immigration tends towards skilled individuals if capital and skilled labour are complementary.

8 Epstein, Hillman and Weiss (1999) demonstrate conditions under which under guest-worker programs result in populations of illegal immigrants.

${ }^{9}$ One exception is a recent policy in Israel under which temporary migrants are forced to save part of their legal earnings, which are received by the worker as a lump sum upon departure from Israel (Brücker et al., 2001, p. 134)

${ }^{10}$ As an illustrative example, simulations of the potential impact of East-West migration in Europe on large states like Germany and the UK has been estimated to be in the order of one percent of GDP - a positive impact if flow consist of skilled workers, and a negative impact if flows are dominated by the unskilled (Bauer and Zimmerman, 1999).

${ }^{11}$ The Irish component of the OECD database is drawn from the 2001 Census of population. For most other OECD countries, the data is derived from Census records in 2001, 2002, or the most recent available year. See Dumont and Lemaître (2003), for preliminary work with this data. 
${ }^{12}$ The stock of immigrants in Ireland is included as part of the tabulations from the 1996 Census of population. Unfortunately, the available data for 1996 is less informative as regards country of origin, with by-birthplace stocks listed only the UK and the EU-15.

${ }^{13}$ Note that Nigerians dominate demands for asylum in Ireland, with about 35 percent of asylum applications in 2003.

${ }^{14}$ The data refer to average years of schooling in each source country among the population aged 15 years and above. The source is Barro and Lee (2000).

${ }^{15}$ The figures are drawn from Nolan and Smeeding (2004)

${ }^{16}$ The letter of the law states that employers must advertise position nationally and throughout the EEA for a minimum of four weeks before searching for workers outside of the EEA.

${ }^{17}$ Occupational categories covered by this scheme include positions in information and computing technology, construction professionals, and medical professionals.

${ }^{18}$ Visa holders must have been in Ireland for three months before being joined by their family.

${ }^{19}$ Immigrants in Canada who identify themselves as Russian have similar third-level qualifications to those in Ireland (57 versus 61). Canadian-based Ukrainians are less well educated than their Irish counterparts (42 percent have third-level education), but these immigrants are likely much older than Ukrainian-born residents of Ireland.

${ }^{20}$ All wage figures are drawn from Ruhs (2003), Figure 19.

${ }^{21}$ Estimates of Gini indices for Latvia and Lithuania, two accession states not included in Table 2, are typically smaller than corresponding estimates for Ireland (World Bank, 2004).

${ }^{22}$ A recent example is Dustmann (2001)

${ }^{23}$ Note also that the benefits of diversity are likely to be larger if immigration is permanent. It would be possible in principle to operate a "balanced" temporary migration scheme, but interactions between the ethnic majority and minority groups are likely to be less frequent if immigrants have a reduced incentive to assimilate into the traditions and culture of the host economy.

${ }^{24}$ The province of Quebec operates a separate immigration policy, in which points allocated to targeted occupations have a substantial influence on the selection process. 


\section{DISCUSSION}

Gerry O'Hanlon: It gives me great pleasure to second the vote of thanks to Chris for a stimulating and enjoyable paper. The paper is also very timely in that we in Ireland as a nation must adjust very rapidly to an entirely new situation brought on by significant immigration over the past 5 to 10 years.

In responding to the paper I would like to focus on three aspects, namely:

- $\quad$ Recent migrant trends and likely developments over the medium term;

- $\quad$ The socio-demographic profile of the non-national population revealed by the 2002 Census; and

- $\quad$ Some issues around the statistical definition and measurement of migration.

\section{Migrant trends}

Net inward migration has been running at about 30,000 per annum in recent years and this has been contributing about $3 / 4 \%$ a year to annual population - roughly the same impact as the natural increase component. As mentioned in the paper the profile and source of the immigrants has also been changing rapidly. As a consequence, the stock of non-Irish nationals, as a percentage of the total population, more than doubled between 1996 and 2002 to stand at close to 6\% at the end of the period.

While projecting future migration flows is always a hazardous occupation we can, I believe, be fairly certain that there will be a significant continued inflow over the short to medium term. The key factor in this regard will be the developments in our labour force over the coming years. In the recently published Population and Labour Force Projections, published by the CSO, we drew attention to the fact that the natural increase in our existing population would be capable of sustaining a growth rate of less than $1 \%$ in our labour force over the coming decade or so. This would fall well short of the $2.7 \%$ average annual growth rate recorded since 1991 (and indeed the current rate of growth, which is over $3 \%$ at present). As a crude simulation exercise we demonstrated that sustaining a labour force growth rate of around $2 \%$ per annum would require net annual immigration to continue at around 30,000 while a more modest, by recent standards, $1.5 \%$ growth per annum would need a net inflow of 20,000 each year.

Neither of these labour market scenarios would be considered unreasonable in current circumstances and should they be realised then we can expect our non-national population to rise rapidly, in both absolute and proportionate terms, in the coming years. The new residents are also likely to have more diverse backgrounds than heretofore. Thus, in the space of perhaps half a generation Ireland will have moved from having a very homogeneous population to one that is as diverse as that existing in many other countries with a much longer tradition of immigration.

\section{Profile of Non-Irish nationals, Census 2002}

To illustrate some of diversity that already exists within the non-Irish national population I would like to present three graphics based on the results of the 2002 Census of Population. These focus on the age profile, labour force status and educational attainment of Irish nationals compared with the main groups of non-nationals (i.e. EU 15, Rest of Europe, Africa, Asia and Rest of the World). 
Figure 1: Irish and Non-Irish national by age, 2002

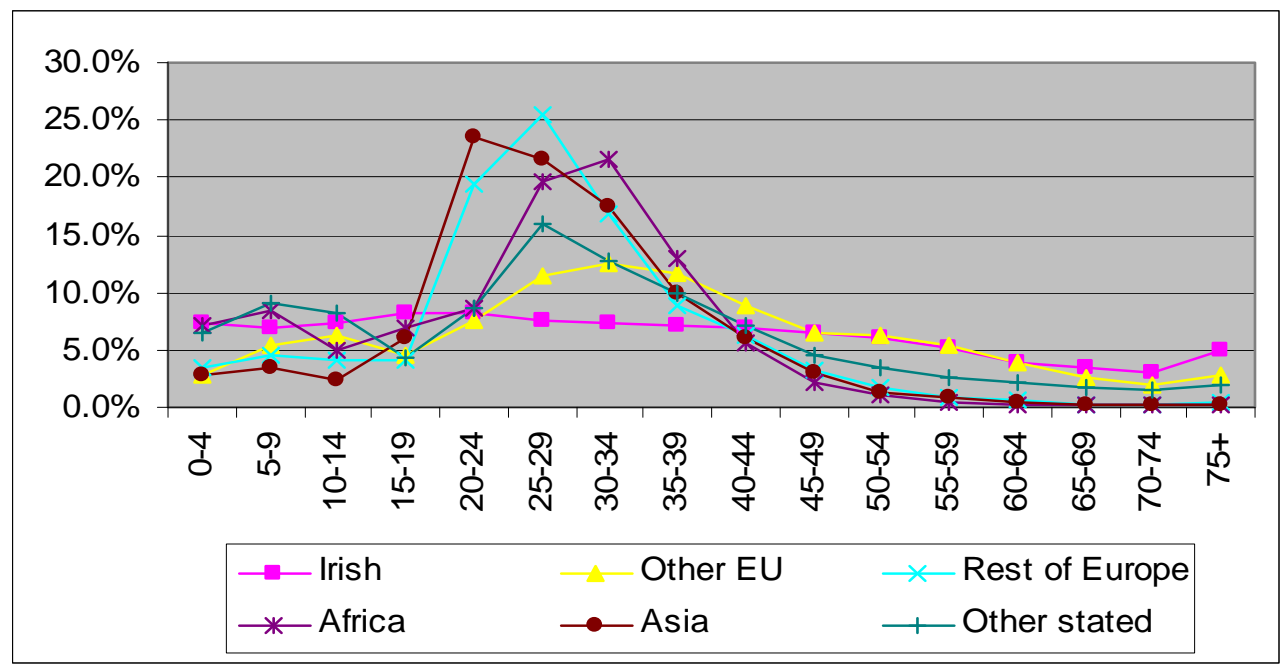

Irish 3.6m; Other EU 133,000; Rest of Europe 23,000; Africa 21,000; Asia 22,000; Other stated 25,000

Figure 2: Labour Force Participation and unemployment (PES), 2002 Persons aged 15-64 years

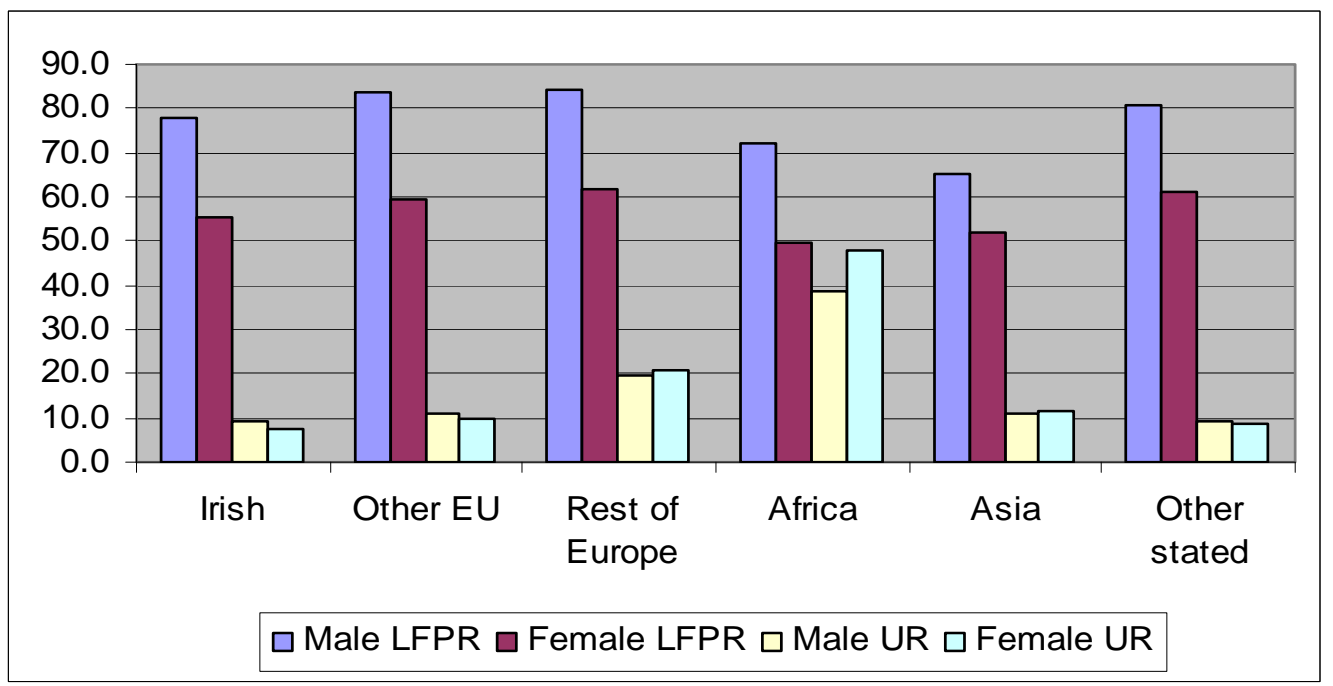

The graphics, I hope, speak for themselves and time does not permit me to go into detail on the differences that may be observed. The main point is that there are significant differences - not only between Irish nationals and non-nationals but also increasingly between the non-national sub-groups - which merit careful analysis. 
Figure 3: Educational attainment - Irish and Non-Irish nationals, 2002

Persons aged 20-44

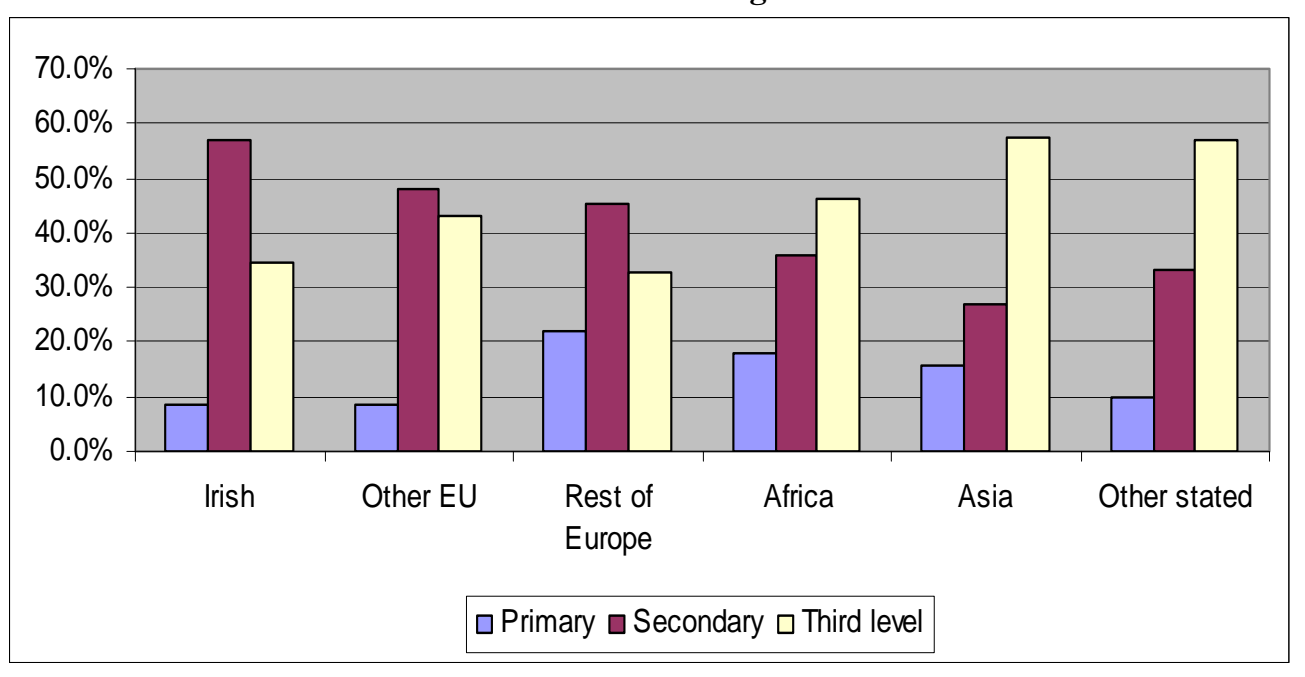

Definition and Measurement of migrants

As befits a statistician, I would like to conclude by drawing attention to the some of the issues that surround the statistical definition and measurement of migrants.

The situation where migration was dominated by the "migrant for life" where the migrant clearly moved permanent residence from one country to another is changing rapidly. In a more global world there is now much greater mobility and flexibility in population movements. Some examples would include: workers commuting across national frontiers between two residences on a weekly basis; young people on a "gap year"; students on language and other courses; contract workers who move from country to country in response to work opportunities etc. The existence of these groups not only gives rise to measurement and interpretation difficulties but also points to the need for more precise statistical definitions.

The concept of "usual residence", as used in censuses and household surveys up to now, is under particular scrutiny and new paradigms may have to be introduced to reflect more accurately the wide variety of circumstances that now pertain.

These are issues that are increasingly taxing the minds of Statisticians and Demographers throughout the developed world - not least in the EU where new agreed definitions are likely to emerge in the not too distant future. In these circumstances my advice to users of migration statistics is to pay particular attention to the metadata before arriving at conclusions!

Once again may I thank Chris for a very interesting presentation and I look forward to further contributions to the Society on this very important topic. 